\title{
Albumin, Globulin Concentration and Total Protein Colostrum Mother Pig Superovulation before Breeding
}

\author{
Revolson A Mege' ${ }^{1}$, Debbie J. J. Rayer ${ }^{3}$ \\ Biology Department \\ Universitas Negeri Manado \\ Manado, Indonesia \\ ${ }^{1}$ ramege@unima.ac.id, ${ }^{3}$ debbierayer@unima.ac.id
}

\author{
Nonny Manampiring ${ }^{2}$ \\ Dinas Pendidikan \\ Kabupaten Minahasa Utara \\ Airmadidi, Indonesia \\ 2Nonnym@gmail.com
}

\author{
Friska M. Montolalu ${ }^{4}$ \\ Biology Department \\ Universitas Trinita \\ Manado, Indonesia \\ ${ }^{4}$ fmontolalu@yahoo.co.id
}

\begin{abstract}
This research aimed to study the effect of PMSG and hCG injection breeding albumin, globulin concentration and total protein colostrum mother pig. This research using 6 months piggy descent of land care with 30 pigs total and the weight average 95-105 $\mathrm{kg}$. Hormone in used are MPSG and hCG before breeding $600 \mathrm{IU}$ dose for 15 pigs mother candidate and the rest injected by $\mathrm{NaCl}$ physiology $0.90 \%$. Sexual standardizing made by injection prostaglandin (PGF2a). Parameter measurement are albumin, globulin concentration and total protein colostrum mother pig. The research finding showed that PMSG and hCG injection before breeding repaired pregnant performance seen by increasingly albumin, globulin concentration and total protein colostrum $(P<0.05)$. Injection of PMSG and hCG which are increasingly albumin, globulin concentration and total protein colostrum.
\end{abstract}

Keywords-PMSG-hCG; colostrum; albumin; globulin; total protein

\section{INTRODUCTION}

Pig livestock as prolific livestock that have a number of children about 8 to 12 in each birth, with an average of three births per year. Based on the Statistical Data of the Directorate General of PKH (Livestock and Animal Health), pork production is the third largest after chicken and beef meat. The contribution of pork production to national meat production is $10.78 \%$ or 342.3 from $3,175.2$ thousand tons. The Development of Pig Population in Indonesia since the year 2012 - 2016 had increased of $1.7 \%$ from 7.9 million (2012) to 8.1 million (2016). While the aspect of increasing production increased by $9.6 \%$ from 232143 tons (2012) to 342346 tons (2016) [1]. However, the productivity of pigs is still not optimal marked by the high mortality rate of neonatal piglets and the low weight of piglets born to weaning [2].
One of the determining factors in the growth of piglets is the condition of the mother's uterus during pregnancy, the availability of pregnancy hormones, especially progesterone and estradiol, as key hormones in lust cycle [3]. The mechanism of action of reproductive hormones begins with the secretion of GnRH by the hypothalamus which works to stimulate the anterior pituitary to secrete FSH and LH. Follicle stimulating hormone works to stimulate the growth and development of ovarian follicles to produce estrogen, while LH works to stimulate the growth and development of the corpus luteum to produce progesterone. After the ovum is fertilized, the development of the zygote and the growth and development of the embryo and fetus are very dependent on the support of the corpus luteum in securing progesterone which plays a role in preparing the uterine environment, stimulating the growth and development of the uterine gland and placenta, and maintaining pregnancy [4].

Various efforts have been made to increase the productivity of sows, among others by improving the ability of the uterus and placenta to support the growth and development of the fetus and mammary gland through increasing endogenous secretion of pregnancy hormones, especially estradiol and progesterone. Endogenous secretion of pregnancy hormones (estradiol and progesterone) can be increased by increasing the number of hormone-producing glands or by increasing the synthetic activity of existing glands. Repairing endogenous secretion of pregnancy hormones can be done in a simple way through superovulation or by injecting PMSG and hCG. This technology has been shown to increase endogenous secretion of pregnancy hormones, especially estrogen and progesterone, and improve the uterine and placental environment during pregnancy which ultimately improves the birth weight of the child [5][6]. 
Increased endogenous secretion of pregnancy hormones has been shown to improve the growth and development of the mammary gland, thereby increasing milk production during lactation [7] which ultimately improves the growth of presumptive and postpartum children [8]. Research on sheep also showed that lambs born by mothers who were injected with gonadotropins before marriage had a better body defense system which was shown by resistance and higher resilience to Haemonchus contortus infection. It is hoped that through superovulation can increase the productivity of the parent seen from the concentration of albumin, globulin and total protein in the parent colostrum.

The attack of pathogenic bacteria or viruses, allergens, toxins and so on almost every day occurs in the digestive tract in newly born piglets. To protect the body from these harmful effects, the digestive tract has a specific (immunological) and non-specific protection mechanism. To produce healthy and superior piglets, grow and develop well, it is also necessary to consume colostrum and milk from the mother because piglets are born almost without antibodies so they are easily infected. With sufficient intake of colostrum and milk, pig growth and development can be increased, mortality rates can be reduced, health status can be increased so as to reduce the incidence of diseases and piglets to survive [9].

Colostrum contains high protein, namely lactalbumin, lactoglobulin, immunoglobulin (IgG1, IgG2, $\operatorname{IgM}, \operatorname{Ig} \mathrm{A}$ ), peptide (lactoferrin, transferrin), hormones (insulin, prolactin, thyroid hormone, cortisol), growth factor, prostaglandin, enzyme, cytokine (tumor necrosis factor- $\alpha$, acute-phase proteins ( $\alpha 1$-glycoprotein), nucleotides, polyamine, minerals (iron, magnesium and sodium salts) [10]. The concentration of most of these ingredients, especially immunoglobulins and growth factors, is the highest in the first portion of colostrum immediately after parturition, and therefore will decrease rapidly thereafter [11]. Therefore, neonatal piglets need sufficient colostrum in order to meet their immune system needs [12].

\section{RESEARCH METHODS}

This research was carried out in commercial pig farms located in Wailan Village, North Tomohon District, Tomohon City, North Sulawesi Province. Analysis of albumin, globulin and total colostrum proteins was carried out at the Laboratory of Microbiology and Immunology of the Primate Animal Study Center (PSSP) Bogor Agricultural University. The animals used were 6-month old pigs from Landrace descents with 30 individuals with body weights about 95 to $105 \mathrm{~kg}$ and the children they produced. Landrace breeds were chosen because of the abundant amount of livestock used for research, and because the Landrace pigs grew faster than other pig populations. The feed given is adjusted to the feed used on the farm.

The sows are kept in individual cages and fed twice in the morning (07.00 WITA) and afternoon (15.00 WITA), drinking water is available ad libitum. The hormones used for superovulation are pregnant mare serum gonadotropin (PMSG) and human chorionic gonadotropin (hCG) (PG 600, Intervet, Netherlands) with a dose of 600 IU per parent, and for prostaglandin is used for un informing lust (PGF2 $\alpha$ ) (Lutalyse,
Intervet, Netherlands) 2 times with an interval of 14 days. In the second PGF2 $\alpha$ injection, or 3 days before lust, PMSG and hCG injections were carried out before intramuscular administration in 15 mothers, while the control group, which was 15 mothers were injected with $0.9 \%$ physiological $\mathrm{NaCl}$ which acted as a control on the treatment.

Piggy in this study were mated to the second lust after puberty. After the piggy has shown symptoms of lust, the male is put into a cage to marry the lustful female. Prospective sows are mated on the second day of estrus with signs of a red vagina, releasing a fairly thick liquid, and when pressed on the back of the pig it is only silent. These signs indicate that the experiment pig is ready to receive a male. Sow will be bred 2 times, in the morning and in the evening on the same day. Parameters measured were albumin, globulin, and total colostrum protein obtained by collecting colostrum samples ( 3 $\mathrm{mL}$ ) in the first milking on the nipple with the largest diameter (3rd nipple) after the mother parturition. The research design used in this study was a Completely Randomized Design (CRD) consisting of 2 treatments and each treatment was repeated 15 times. The sows are kept until parturition, and in the later stages the children born are numbered. The data obtained were analyzed using Independent samples t-Test. Data analysis was carried out using SPSS 20 software.

\section{RESULT AND DISCUSSION}

Research finding shows that the concentration of albumin of the main colostrum when patrus on PMSG and hCG injection treatment is significantly different $(\mathrm{P}<0,05)$ compared to the control. This shows that PMSG and hCG injection on the main can increase the albumin concentration in colostrum as $16397.59 \pm 24566.52(\mu \mathrm{g} / \mathrm{mL})$ compared to the control that has albumin concentration $2095.54 \pm 2252.05(\mu \mathrm{g} / \mathrm{mL})$. Albumin was synthesized and secreted by the hepatosit in liver (Kaneko et al. 2008). Albumin has the capability to bind the ligand and responsible for $80 \%$ of the osmotic pressure (Walker et al 1990). Some previous research has proven that the PMSG and hCG injection on the main part can increase the secretive hormones of pregnancy, the growth and the development of mammary gland, and the milk production of the sheep [5], and goat [13]. The hormone of pregnancy does have role on the stimulation and the growth and the development of uterus, placenta, and mammary gland. This research finding proves that PMSG AND Hcg injection can increase the concentration of albumin in main colostrum to fulfill the new born baby's need.

TABle I. The Average Concentration of Albumin, Globulin COLOSTRUM, TOTAL PROTEIN

\begin{tabular}{|c|c|c|}
\hline \multirow{2}{*}{ Parameter } & \multicolumn{2}{|c|}{ Treatment } \\
\hline & Control & PMSG-hCG \\
\hline $\begin{array}{l}\text { Albumin } \\
\text { colostrum } \\
(\mu \mathrm{g} / \mathrm{mL})\end{array}$ & $2095.54 \pm 2252.05^{\mathrm{a}}$ & $16397.59 \pm 24566.52^{b}$ \\
\hline $\begin{array}{l}\text { Globulin } \\
\text { colostrum } \\
(\mu \mathrm{g} / \mathrm{mL})\end{array}$ & $228390.68 \pm 160931.1^{\mathrm{a}}$ & $449937.59 \pm 157952.84^{b}$ \\
\hline $\begin{array}{l}\text { Total Protein } \\
(\mu \mathrm{g} / \mathrm{mL})\end{array}$ & $230324.83 \pm 162794.99^{a}$ & $465657.94 \pm 173354.01^{b}$ \\
\hline
\end{tabular}


Globulin concentration in main colostrum when partus is on injection treatment of PMSG and $\mathrm{hCG}$ in significantly different $(\mathrm{P}<0,05)$ compared to the control. This thing shows that the injection of PMSG and hCG in the main part can increase the globulin concentration in colostrum that is $449937.59 \pm 157952.84(\mu \mathrm{g} / \mathrm{mL})$ compared to the control that has concentration i.e. $228390.68 \pm 160931.1(\mu \mathrm{g} / \mathrm{mL})$. According to [14], globulin is taking care of ion circulation, fatty acid hormone, and in immune system. Several types of globulin bind hemoglobin, some other carry on iron, to resist infection, and has a role as

Coagulation factor. [15] report that the lacking of globulin will cause the immunodeficiency. The antibody is produced by lymphocytes B that has already matured and has changed the name become cell plasma. Gamm globulin, besides it is formed in liver, also formed in spleen and bone marrow. The level of globulin in blood can be affected by age, protein content in woof, and the activity of lymphoid cell in producing the globulin. The decrease of globulin level in blood is relating to the low of body immune so that body is susceptible to the decease [14].

Total concentration of protein on mother colostrum in parturition time at the PMSG injection treatment and hCG significantly different $(\mathrm{P}<0,05)$ compare to the control. This thing showed that the injection of PMSG and hCG to the mother could increase total protein concentration in the colostrum which is $465657.94 \pm 173354.01(\mu \mathrm{g} / \mathrm{mL})$ compare to the control that possessed total protein concentration which is $230324.83 \pm 162794.99(\mu \mathrm{g} / \mathrm{mL})$. According to [16] health state can be seen from the various aspects, one of them is through the observation on blood protein level. [14] reported that the high and the low of total blood protein concentration in the related with body's health state. Concentration of total protein in the blood affected by some factors among others age, stress because of the extreme climate, and the nutritional content in the given feed. Total protein concentration in the blood also affected by the amount of protein in the given feed. Protein in the feed will contribute influence directly on the total protein level in the blood. According to [17], protein is beneficial to substitute the damaged tissue, creating antibody, enzyme and hormone, preserving the wet acid, water, electrolyte, even distributing the amount of energy to the body.

\section{CONCLUSION}

The usage of PMSG and hCG before mating of the mother could increase albumin concentration, globulin and protein total in the colostrum of mother pig that holds the role in body immune mechanism towards the infection on the neonates' baby pig. With the mechanism of good body immune towards the infection so that neonates baby pig will have a well growth performance and have high life expectancy.

\section{ACKNOWLEDGMENT}

We would like to thank to DRPM Kemenristek Dikti RI for supporting this research.

\section{REFERENCES}

[1] Ditjennak, Statistika Peternakan, Jakarta, 2016.

[2] R.S. Cutler, V.A. Fahy, G.M. Cronin, E.M. Spicer, B.E. Straw, J.J. Zimmerman, S.D. D'Allaire, D.J. Taylor, Preweaning mortality: Diseases of Swine, 9th ed., Hoboken: Blackwell Publishing Ltd. 2006.

[3] R.H.E. Sendouw, S.B. Kairupan, and R.A. Mege, "Applied entrepreneurship education at University of Manadonorth Sulawesi Indonesia,” Int. J. Eng. Technol., vol. 7, no. 3, 2018.

[4] H. Caárdenas and W.F. Pope, "Control of ovulation rate in swine 1," J. Anim. Sci., vol. 80, pp. E36-E46, 2002.

[5] W. Manalu, M.Y. Sumaryadi, and A.S. Satyaningtijas, "The effect of superovulation of Javanese thin-tail ewes prior to mating on lamb birth weight and preweaning growth.," Asian-Australasian J. Anim. Sci., vol. 13, no. 3, pp. 292-299, 2000.

[6] R.A. Mege, W. Manalu, N. Kusumorini, and S.H. Nasution, "Pengaruh superovulasi terhadap produksi anak babi," J. Anim. Prod, vol. 8, pp. 14-18, 2006.

[7] W. Manalu, M.Y. Sumaryadi, and A.S. Satyaningtijas, "Mammary gland differential growth during pregnancy in superovulated Javanese thin-tail ewes," Small Rumin. Res., vol. 33, no. 3, pp. 279-284, 1999.

[8] D.J.J. Rayer, H. Maheswari, M. Muladno, and W. Manalu, "Production of Superior Pigs by Injecting the Sows with Gonadotropin Prior to Mating," Anim. Prod., vol. 17, no. 1, pp. 8-15, 2015.

[9] R.A. Cabrera, X. Lin, J.M. Campbell, A.J. Moeser, and J. Odle, "Influence of birth order, birth weight, colostrum and serum immunoglobulin G on neonatal piglet survival," J. Anim. Sci. Biotechnol., vol. 3, no. 1, p. 42, 2012.

[10] J.W. Blum, "Nutritional physiology of neonatal calves," J. Anim. Physiol. Anim. Nutr. (Berl)., vol. 90, no. 1-2, pp. 1-11, 2006.

[11] R.J. Playford, C.E. Macdonald, and W.S. Johnson, "Colostrum and milk-derived peptide growth factors for the treatment of gastrointestinal disorders-," Am. J. Clin. Nutr., vol. 72, no. 1, pp. 5-14, 2000.

[12] W.L. Hurley and P.K. Theil, "Perspectives on immunoglobulins in colostrum and milk," Nutrients, vol. 3, no. 4, pp. 442-474, 2011.

[13] I.K.S. Adriani, A. Sudono, T. Sutardi, and W. Manalu, "Pengaruh superovulasi sebelum perkawinan dan suplementasi seng terhadap produksi susu kambing Peranakan Etawah,” J. Ilmu Ternak, vol. 6, no. 2, pp. 86-94, 2004.

[14] J.E. Kaslow, Analysis of Serum Protein. Santa Ana: 720 North Tustin Avenue Suite 104, 2010.

[15] L. C. Junqueira, J. Carneiro, and R. O. Kelley, Basic histology: text \& atlas, vol. 11. New York: McGraw-Hill, 2003.

[16] H.K. Walker, "The origins of the history and physical examination," 1990.

[17] T. Kresnawan and H.M.S. Markun, "Diet Rendah Protein Dan Penggunaan Protein Nabati Pada Penyakit Ginjal Kronik.” 2012. 